DOI: 10.31862/2500-2953-2019-1-20-35

\title{
Н.Р. Конкина
}

Институт русского языка им. В.В. Виноградова РАН, 119019 г. Москва, Российская Федерация

\section{Текстовое ассоциативное поле пространственного предела (на материале «Словаря языка Достоевского»)}

В статье предлагается метод реконструкции текстового ассоциативного поля с использованием материала «Словаря языка Достоевского». Приводится алгоритм моделирования текстового ассоциативного поля пространственного предела с привлечением ресурсов словаря. Идиоглоссы, рассматриваемые в статье, входят в состав одной символической парадигмы, и более полное описание символического значения каждой из них достигается путем сопоставительного анализа контекстов их употребления. Кроме этого, проводится сравнение данных «Словаря языка Достоевского» и «Русского ассоциативного словаря», что позволяет выделить некоторые особенности функционирования слов со значением пространственного предела в русской языковой картине мира.

Ключевые слова: словарь языка Достоевского, текстовое ассоциативное поле, идиоглосса, ассоциативные связи.

\section{N. Konkina}

\section{Associative text field of spatial limit (on the material of the "Dostoevsky Language Dictionary")}

The paper offers the textual associative field reconstruction method using the "Dostoyevsky Language Dictionary". The logic of modelling the textual associative field of spatial border is applied to the Dictionary's data. The idioglosses 
described in the paper are included in the same symbolic paradigm so the more detailed symbolic meaning description is possible by comparing the contexts of their use. Besides, the comparison of "Dostoyevsky Language Dictionary" and "Russian Associative Dictionary" data allows finding some peculiarities of the words with the spatial border meaning functioning in Russian linguistic world-image.

Key words: Dostoyevsky language dictionary, textual associative field, idioglossa, associative links.

Подход к языку как к «лингвистической компетенции говорящего на нем индивида» [Караулов, 1999, с. 9] привел к необходимости составления ассоциативно-вербальной сети, включающей множество связанных между собой ассоциативных полей (АП). Традиционно данные о составе поля, фиксируемые в ассоциативных словарях (например, «Русский ассоциативный словарь» (РАС)), получают в ходе ассоциативного эксперимента с носителями языка, суть этого эксперимента обычно заключается в сборе и обработке реакций, полученных на тот или иной стимул. Однако ассоциативные связи существуют не только в потенции, но и в виде текстовых реализаций, что дает возможность реконструировать фрагмент ассоциативно-вербальной сети с помощью ассоциативного анализа текста, продуцированного языковой личностью.

Текст, реализующий языковую готовность носителя языка, представляет собой совокупность «расчлененных», линейно выстроенных АП, а построенное на его основе текстовое ассоциативное поле (ТекстАП) является коррелятом традиционного АП. Метод реконструкции ТекстАП впервые был предложен и описан Юрием Николаевичем Карауловым [Караулов, 2015], а результатом такого подхода стал «Словарь языка Достоевского» (СЯД), словарная статья которого является вариантом представления выделенных из текстов Ф.М. Достоевского и представленных нелинейно единиц того или иного ТекстАП.

По замыслу составителей СЯД, основным элементом ТекстАП является идиоглосса - обязательная единица индивидуального авторского лексикона, которая несет «ключевые идеи его миропонимания, характеризует неповторимый идиостиль автора» [Караулов, Гинзбург, 2002, c. XIV]. Подробный лингвистический комментарий, содержащийся в СЯД, позволяет построить ТекстАП идиоглоссы с использованием ресурсов разных зон комментария - ассоциативного окружения слова, его подчинительных и сочинительных связей, символического употребления, использования слов одного словообразовательного гнезда в одном контексте и т.д. В настоящей статье ставится задача определить возможность использования данных СЯД с целью реконструкции ТекстАП на материале группы слов со значением пространственного 
предела, куда входят следующие идиоглоссы, выделенные из словника СЯД (в скобках указана абсолютная частота словоупотреблений во всех текстах Ф.М. Достоевского): порог (131), граница (513), край (141), дверь (1260), окно (673), ворота (242), калитка (39), крыльцуо (145), забор $(114)^{1}$.

Идиоглоссы, входящие в исследуемую группу, являются словамисимволами, которые в творчестве Ф.М. Достоевского «следует рассматривать в качестве своеобразных ядерных элементов, организующих авторский тезаурус» [Ружицкий, 2014, с. 132]. В качестве гипотезы исследования выдвигается положение о том, что сопоставительный анализ функционирования идиоглосс, входящих в состав одной парадигмы, дает возможность наиболее полно описать символическое значение каждой из них.

Обратимся к исследуемой группе слов, доминантой которой является слово порог, сочетающее в себе общее значение предела, границы жилого помещения, а также места, где границу можно преодолеть. Порог (который в разных источниках часто подразумевается под словом дверь) обладает общекультурным символическим значением и «является традиционным пограничным локусом», с которым «связана идея входа и выхода» [Кирло, 2010, с. 138]. Идея порога как границы между миром живых и мертвых осмысляется человеком в категориях привычного быта и переносится на порог его собственного жилища. Так, с порогом у разных народов связаны многие обряды перемены статуса, включающие лиминальную стадию [Тэрнер, 1983], а у восточных славян отмечается большое количество запретов, связанных с нахождением на пороге (не сидеть на пороге, не разговаривать через порог, не переступать первым порог нового жилища и т.д.) [Байбурин, 1983].

В работах исследователей творчества Ф.М. Достоевского символическому значению порога уделяется большое внимание. Г. Гессе писал о «Братьях Карамазовых» как о романе, где «воссоздан порог, который ныне переступает Европа», «этот тревожный, опасный момент неизвестности на переходе между ничто и всем» [Гессе, 2010, с. 326], т.е., по мнению автора, порог - это область пустоты между двумя состояниями, которую необходимо преодолеть, чтобы оказаться в каком-то новом мире. М.М. Бахтин указывал на то, что порог получает значение «точки», где совершается кризис, радикальная смена, неожиданный перелом судьбы, где принимаются решения, переступают запретную

\footnotetext{
${ }^{1}$ Приведенный ряд может быть расширен словами ширма и стена, которые являются важными элементами тезауруса Ф.М. Достоевского, но не имеют опубликованных в настоящий момент статей в СЯД.
} 
черту, обновляются или гибнут. Этот тезис иллюстрируется примерами из «Преступления и наказания»: на пороге, в проходной комнате живет семья Мармеладова, на пороге происходит сцена немого признания Разумихину и т.д. [Бахтин, 1979, с. 198]. Д. Арбан отмечает важную для понимания произведений Ф.М. Достоевского деталь: «порог заставляет того, кто переступает, совершить действие, сделать шаг» [Арбан, 1976, c. 19]. В романах герои предстают перед читателем в разные моменты жизни: они уже переступили порог (Ставрогин), готовы переступить (Раскольников), находятся на протяжении всего романа на пороге, пытаясь найти решение (Иван Карамазов). Шаг совершённый или ожидаемый может быть связан, например, с испытанием, через которое они проходят: убийство, самоубийство или принятие важного решения [Карасев, 1994].

В статье порог в СЯД на основании материалов зоны иллюстраций выделяются более конкретные значения:

1) 'граница своего и чужого пространства';

2) 'начало пути';

3) 'рубеж, крайняя точка'.

С первым значением связаны такие ассоциации, как войти, впустить в дом, вход, гость, дверь, перешагнуть и т.д. При этом порог часто фигурирует как место действия: человек останавливается на пороге, не желая или опасаясь полностью пересечь границу. Это наблюдение подтверждается количеством подчинительных сочетаний с синтаксемой на пороге, которое составляет половину соответствующей зоны комментария: на пороге встретить, выступить, завязнуть, лечь, останавливаться, остановиться, постоять, стать и др.

Обратимся к роману «Униженные и оскорбленные», где практически все ключевые сцены происходят на пороге. В этом романе символическое значение порога как границы дополняется ассоциативной связью порог - унижение. Для героев, претерпевших несчастья и унижения, морально сломленных, порог - важное место, разделяющее безопасное пространство дома и внешний мир. Так, на пороге происходит эмоциональное примирение старика Ихменева и Наташи. Беседы Нелли и главного героя очень часто происходят на пороге и до, и после того, как она стала жить в его комнате. Девочка задерживается на пороге неслучайно: она недоверчива, поэтому не может и не смеет пересекать границу чужого пространства быстро. Когда Нелли привыкает к своему новому дому, она тщательно запирает дверь и ждет Ивана Петровича на пороге, иногда даже засыпает там.

Второе значение 'начало пути' реализуется, например, в таком контексте: Казалось, сама судьба остановила меня на пороге в новую жизнь 
[Достоевский, т. 2, с. 316]. Третье значение находим в примерах, вынесенных в зону тропеического употребления: Именно эти самые англичане, с таким материнским участием оберегающие теперь неприкосновенность Туриии <...> именно они-то, когда увидят, что дело дошло до порога, именно они-то и скушают султана и Константинополь [Там же, т. 13, с. 284].

Значения, выделенные в СЯД, соотносятся с группами ассоциаций из статьи порог в РАС:

1) 'граница': дома, дверь, переступить, крыльцо, входить, дома моего, переступать, перешагнуть;

2) 'начало пути': жизни, уйти, эра;

3) 'рубеж, край': последний, бедности, скорость, сльшиимости.

Идиоглосса граница входит в ТекстАП пространственного предела в значении 'пределы чего-л. материального или духовного; ограничения, рамки'. Особенно ярко оно реализуется в зоне устойчивых словосочетаний: быть в должных гранииах, вывести из грании, выйти из грании, держать в границах и т.д. В зоне комментария обращает на себя внимание нестандартная сочетаемость этого слова: Сошелся я с ними, поневоле сошелся, хотя всегда был от них в пристойных границах [Там же, т. 1, с. 87]. Большинство реакций в РАС на стимул граница (на замке, государственная, страны, пограничник и т.д.) соответствуют двум другим значениям идиоглоссы: 'линия раздела между владениями, областями, государствами' и 'территория, прилегающая к границе', которые, однако, не относятся к исследуемому полю. Реакции предел (2), допустимого (1), слова (1), совести (1) могут быть связаны с переносным значением слова граница, но их количество невелико и частотность минимальна.

На слово-стимул край в «Русском ассоциативном словаре» (РАC) были получены реакции, например, далекий, область, соотносимые с первым значением в СЯД 'область, сторона, территория, местность', а также ассоциации родной, родина, любимылй, нам, родимыгй, мой и т.д., которые указывают на связь слова край с местом происхождения или проживания. В СЯД в зоне тропеического употребления слова зафиксированы контексты с реализацией другого значения: $O$, вы не бродите с краю, а смело летите вниз головой. Вы женились по страсти к мучительству, по страсти к угрызениям совести, по сладострастию нравственному [Там же, т. 7, с. 242], Я сделала вывод и приняла за правило ласкать молодежь и тем самым удерживать ее на краю [Там же, c. 284]. Здесь значение идиоглоссы край сближается с порогом, границей, обозначающими также нравственные и моральные ограничения. 
Несмотря на то, что слова исследуемой группы имеют конкретнопредметные значения, это не лишает их возможности обретать символическое значение, напротив, «чем конкретнее семантика слова, тем большим символическим потенциалом это слово обладает» [Ружицкий, 2008 , с. 58]. Например, Ю.Н. Караулов рассматривает слово дверь «однозначное, с прозрачной семантикой» [Караулов, 2014, с. 125] и отмечает, что при прочтении иллюстративной зоны статьи дверь в СЯД обращает на себя внимание тот факт, что двери «могут быть либо открытыми или открываемыми, либо закрытыми или закрываемыми» [Там же, с. 126]. При произведении подсчетов по данным зон, учитывающих подчинительные и сочинительные связи слова, оказалось, что в произведениях Достоевского двери оказываются открыты в 60\% случаев (непритворенная, была отперта, не затворялась, простояла настежь, скрипнула и приотворилась, отворять и т.д.). В РАС в статье дверь около $40 \%$ реакций описывают ситуации с закрытой дверью (закрытая, заперта, закрой, заклинило, захлопнулась, звонить и т.д.), а в 60\% ситуаций дверь открыта (например, дверь открытая, открыть, настежь, приоткрыта, щель, распахнулась и т.д.). Из этого сравнения следует, что особенность авторской языковой личности выражает свойство русского языкового сознания, которое «предпочитает “видеть” дверь открытой» [Там же, c. 128].

Дверь, как и порог, задерживает входящего или выходящего, заставляя его остановиться. В зоне подчинительных связей в статье СЯД дверь представлено большое количество словосочетаний, называющих остановку в дверях или возле них: возле двери сидеть; возле дверей стоять, около дверей быть, поместиться; от дверей два шага; подле двери прижаться, сидеть; подле дверей останавливаться; против двери остановиться; против дверей стать, стоять, остановиться; у двери место, лежать и т.д.

При этом именно в дверях стоят или задерживаются герои перед тем, как совершить важное для развития романа действие: сделать неожиданный или не вполне приличный визит, открыть тайну, угрожать и др. Например, в дверях стоят князь Мышкин, Ганя и Коля, когда наблюдают за сценой, которую устроила Настасья Филипповна в доме Птицыных. Стоя в дверях, Николай Ставрогин, пришедший с визитом к матери, должен «не сходя с этого места» [Достоевский, т. 7, с. 175] ответить на вопрос Варвары Петровны о его браке.

В РАС на слово-стимул дверь не зафиксированы ассоциации, называющие остановку в дверях, а в обратном словаре для словоформы в дверях упоминается только стимул появиться.

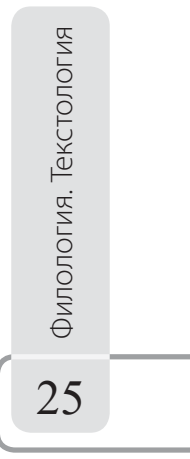


В словарной статье окно в зоне иллюстраций отсутствуют контексты, где описывается ситуация открытого или открывающегося окна, а в ассоциативной зоне, соответственно, есть реакции, дающие представлении только об окне, в котором ничего нельзя увидеть или которое нельзя открыть: занавеска, решетка, ставни, шторы. Все эти препятствия не дают героям Достоевского увидеть того, что происходит за окнами, и, надо отметить, они чаще всего заглядывают в окна с улицы, со двора или из сада внутрь помещения. Так, Голядкин рассматривает со двора окна Олсуфия Ивановича, которые занавешены красными гардинами, а позже такие же красные гардины появляются в «Неточке Незвановой». Девочка смотрит из маленького окошка верхнего этажа на улицу и страстно желает увидеть людей, веселящихся за окном. Маленькое высокое окошко отделяет ее от внешнего опасного и чужого мира, а большие окна и гардины «дворца» - от мира, где люди живут «в вечном празднике и в вечном блаженстве» [Достоевский, т. 2, c. 229]. Окна дома Рогожина, всегда запертые на его половине, дополнительно закрывают белые шторы, что замечает князь Мышкин, наблюдающий за домом с тротуара.

По данным РАС, самыми частотными реакциями на стимул окно являются следующие: спальни, в мир, в Европу, открыто, большое, чистое, свет, в сад, открытое, открыть, светлое, в спальне, широкое, ветер, вид. Во-первых, большинство ассоциаций связаны с открытым большим окном, во-вторых, преобладает взгляд из помещения на улицу, в свободное пространство.

Несмотря на то, что окна, как и дверь, несут функцию «обеспечения проницаемости границы» [Байбурин, 1983, с. 135], между ними существует значительная разница. Войти через дверь значит войти открыто, в то время как окно служит для тайного входа или подачи тайного сигнала: в «Хозяйке» в окно Катерины влезает по веревке Мурин, Наташа Ихменева выставляет свечку на окно в знак ожидания Ивана Петровича, Фёдор Павлович ждет условного оконного стука Грушеньки, а в рассказе старца Зосимы таинственный посетитель попадает в дом жертвы через окно. В зоне подчинительных связей слова зафиксированы следующие сочетания: в окно стук, войти, вскарабкаться, глядеть, завидеть, заглянуть, поглядеть, поглядывать, посмотреть, постучать, постучаться. Отметим, что в описанных ситуациях посредством окна к герою попадает не тот человек, которого он ожидает, а другой, несущий с собой угрозу.

В РАС статья окно включает только одну ассоциацию выход, связанную со входом через окно или сигналом, а в обратном словаре встречаем стимулы войти, стук, стучать, украл, ход, войти, вор. 
В повести «Кроткая» окно является границей между миром живых и мертвых, которую решается пересечь героиня. Такая функция окна издавна имеет место в обрядах разных народов, где «через окно осуществляется символическая связь с миром мертвых» [Байбурин, 1983, с. 141] (например, таким образом славянская традиция предписывала выносить покойников в случае, если человек умер от болезни или неестественной смертью). Зона подчинительных связей слова включает такие сочетания, как из окна выброситься, выпрыгнуть, дергать, соскочить, чуть не вылезти, в окно броситься, выйти, в то время как в РАС обнаруживаются только две ассоциации, соответствующие названному значению, - в мир иной, жизнь, а в обратном словаре встречается стимул морг.

Значением пространственного предела обладает также идиоглосса ворота, например, в составе фразеологических единиц, зафиксированных в СЯД: вытолкать за ворота, отворять ворота [встречать] ( а я, ни слова не говоря, потихоньку, еще больной, сел в вагон да и еду: отворяй ворота, братеи Семен Семеныч! [Достоевский, т. 6, с. 12]). В зоне ассоциаций комментария обращает на себя внимание ассоциат встреча, значение которого реализуется в подчинительных связях слова: у ворот видеться, встретить, встретиться, встречать, дожидаться, ждать, заметить, караулить, нагнать, поджидать, подстерегать, поймать. Интересно, что среди перечисленных глаголов есть такие, которые описывают ситуацию тайного ожидания, скрытого наблюдения: караулить, поджидать, подстерегать. Стоять, остановиться в воротах значит задержаться между двумя мирами - своим и чужим - перед тем, как изменить свою жизнь и себя. В романе «Преступление и наказание» Раскольников перед убийством дважды проходит сквозь ворота. В первый раз он, сбитый с толку тем, что не смог раздобыть топор в кухне, «остановился в раздумье под воротами» [Там же, т. 5, с. 72] своего дома. Он мог бы вернуться домой или пойти на улицу, но и то и другое было ему «противно», потому что это означало бы потерю решимости, отказ от «идеи» [Там же, т. 6, с. 12]. Там же, в подворотне, Раскольников увидел топор дворника и взял его, никем не замеченный. Второй раз он проходит под воротами дома старухи-процентщицы: здесь уже не задерживается, но незаметно проскальзывает во двор за стогом сена. Подворотня воплощает собой материальный аналог той нравственной, духовной границы, которую пересекает Раскольников, а также является местом, где происходит решающее исход дела событие.

В РАС на стимул ворота не зафиксированы ассоциации, связанные с ситуацией тайной встречи или ожидания, однако в других статьях, 
например, ожидание, есть реакции у ворот 1, у двери 1, а отсутствие реакций, включающих сему 'ждать', в статье ворота можно объяснить грамматической формой стимула (вместо у ворот). В этой статье также нет ассоциаций, связанных с принятием важных решений или совершением греховных дел, а частотные ассоциации в рай, в ад лишь демонстрируют связь с соответствующими клише.

Элементом ворот часто выступает калитка, ведущая во двор: например, через открытую калитку в воротах смотрит герой романа «Униженные и оскорблённые» на сцену с избиением Нелли. Калитка может быть садовой: калитка в сад Карамазовых перед убийством Фёдора Павловича стоит отпертой. В статье калитка встречается только одна ассоциация, связанная с закрытым пространством, а в зоне подчинительных связей находим сочетания калитка отпертая, стоявщая отпертой, настежь, отворилась, отворена и т.д. Николай Ставрогин уходит от Шатова после признания и, шагая через калитку, говорит, что больше к нему не придет, а после Шатов забывает запереть калитку, через которую к нему входит Эркель, чтобы дать ложную надежду и пригласить на место будущего убийства. Во всех описанных ситуациях открытая калитка приводит в дом беду.

В РАС реакция открыта (в разных формах) на стимул калитка зафиксирована в общей сложности 11 раз, закрыта - 6. Кроме этого, вторым по частотности в статье указано слово дверь, а также есть ассоциация дверка, что говорит о тесных ассоциативных связях между калиткой и дверью.

Среди контекстов употреблений идиоглоссы крыльцо встречаются такие, где крыльцо функционирует как сцена: на крыльцо всходит Келлер, чтобы произнести речь перед публикой; стоящую на крыльце Настасью Филипповну вслух обсуждает толпа, комментируя ее внешний вид. Крыльцо в таких контекстах играет роль возвышения, является открытым пространством, не скрывающим находящегося там человека. В зоне ассоциаций присутствуют соответствующие этому значению слова: визит, парадная лестница, народ, прием. В РАС слово крыльио не представлено в качестве стимула, однако в обратном словаре отмечаются стимулы, соответствующие представлению о крыльце как о месте: место, выйти, стоять.

С другой стороны, крыльцо не теряет значения границы: с крыльца Настасья Филипповна должна сойти, чтобы отправиться на венчание, но она замечает в толпе Рогожина и бежит к нему - решение принято. В предпоследней главе Рогожин и князь Мышкин входят в дом тайно с крыльца с тем, чтобы перейти границу между миром реальным 
и безумным. Ассоциативную связь крыльцио - порог находим и в РАС: на слово-стимул порог четыре раза была дана реакция крыльцо, и это шестой по частоте показатель.

Зона ассоциаций в статье забор включает слова глухой, страшный, высокий, крепкий, ограда, стена, и только один ассоциат перескочить связан с идеей преодоления забора. В иллюстрациях нет ни одного контекста, где забор имел бы положительную коннотацию, например, 'защита'. Напротив, забор представляется досадной преградой на пути: попасть же в него, кроме этого входа, нельзя было, потому что кругом всего сада шел крепкий и высокий забор [Достоевский, т. 9, с. 89]. Забор может также ассоциироваться со смертью в нищете и забвении, в частности, в устойчивых сочетаниях умереть под забором, смерть под забором и в модификации издохнуть у забора, замерзать под забором. Так, Степан Верховенский часто угрожает Варваре Петровне тем, что кончит жизнь свою гувернером у купца или смертью под забором, а герой романа «Подросток» после сильного эмоционального потрясения теряет сознание и остается лежать под забором. При этом в бреду ему хочется влезть на забор и устроить пожар, но он не может забраться на него и падает.

Следует подробнее остановиться на ассоциативной связи забор перескочить и семантически близких к ней подчинительных сочетаниях из соответствующей зоны: забор перелезать, перескочить, через забор проникнуть. В СЯД указано, что все эти сочетания употребляются в романе «Братья Карамазовы», в сцене, когда брат Дмитрий проникает в сад отца, чтобы найти Грушеньку. Этот поступок оказывается для Дмитрия роковым, и автор подчеркивает, что герой перелезает забор именно в том месте, где когда-то это сделала Лизавета Смердящая.

В РАС в статье забор можно выделить две частотные ассоциации высокий и проволока, которые включены в состав других реакций имплицитно или эксплицитно: высок, высокий и крашеный, высокий с колючей проволокой, из колючий проволоки, зубчатый, колючий, проволока, с проволокой. В статье есть и другие ассоциации, связанные со значением 'ограничение свободы': длинный, большой, бесконечный, неволя, преграда, ставить, стоит. Однако здесь же присутствуют ассоциации доски, дыра, доска, дырка, с дыркой, щель, т.е. такие, которые указывают на неоднородность преграды, наличие места, где границу можно пересечь. Другие ассоциации, связанные с преодолением границы, - перелезть, кончился, перепрыгнуть, подвинуть, сломался, снесён, упал. 
Близкой по символическому значению идиоглоссой для забора оказывается стена. Несмотря на то, что в СЯД статья стена еще не опубликована, нельзя не отметить тот факт, что в работах, посвященных исследованию символического значения этого слова, часто встречается точка зрения, которая заключается в понимании стены как символа отчужденности, разъединенности с миром, ограничивающей человеческое существование, а также преграды, которую никто не в силах преодолеть (см. [Горбунова, 1992; Венедиктова, 2008; Криницын, 2009] и т.д.). В «Записках из Мёртвого дома» слово стена употребляется в составе фразеологизма идти до самой последней стень [Достоевский, т. 3, с. 304], а в «Записках из подполья» используется вариант дойти до последней стены [Там же, т. 4, с. 456]. В обоих случаях это сочетание служит для описания ситуации, которая останавливает даже самых уверенных, активных, бесстрашных людей и либо губит их, либо заставляет отступить. Материал РАС включает следующие ассоциации для стимула стена: глухая, непробиваемая, преграда, толстая, камень, крепость, бетонная, непреодолимая, неприступная, непроходимая, безысходность, как нам быть, тюрьма, тупик и т.д. Интересна ассоциативная пара стена - забора, которая указывает на близкую связь в представлениях о заборе и стене как о монолитном неприступном препятствии.

Слово ширма, входящее в ТекстАП пространственного предела, в настоящее время не включено в список идиоглосс [Ружицкий, 2015], т.к. приобретает особую значимость преимущественно только в повести «Кроткая». Ширма и отдельная кровать становятся «знаком расторжения брака» [Там же, с. 235], полного отделения одного человека от другого. Несмотря на то, что других произведений, в которых упоминается ширма, немного (например, написанные ранее «Господин Прохарчин» и «Подросток»), это слово, по нашему мнению, претендует на статус идиоглоссы. Основанием может служить тот факт, что ширма относится не только к ТекстАП пространственного предела, но и к полю женить$б a$ и его семантической зоне разрыв, а также к ТекстАП строгость [Караулов, 2015]. Включенность лексической единицы текста в разные поля делает ее значимым тезаурусообразующим понятием, что является важнейшим показателем статуса идиоглоссы. В то же время такие показатели, как повторяемость и сквозной характер единицы, являются необязательными условиями соответствия статусу идиоглоссы [Караулов, Гинзбург, 2002].

Результатом проведенного выше анализа функционирования идиоглосс и сравнения материала двух словарей является таблица, резюмирующая все сказанное (табл. 1). 
Символические значения идиоглосс, входящих в состав текстового ассоциативного поля пространственного предела, по данным словарей

\begin{tabular}{|c|c|c|}
\hline Идиоглосса & Характеристики по СЯД & Характеристики по РАС \\
\hline Порог & $\begin{array}{l}\text { 1) граница; } \\
\text { 2) начало пути; } \\
\text { 3) крайняя точка; } \\
\text { 4) пространство, место }\end{array}$ & $\begin{array}{l}\text { 1) граница; } \\
\text { 2) начало пути; } \\
\text { 3) крайняя точка }\end{array}$ \\
\hline Граница & 1) рамки нравственных норм & $\begin{array}{l}\text { Hа периферии: } \\
\text { 1) рамки нравственных норм }\end{array}$ \\
\hline Край & 1) рамки нравственных норм & $\begin{array}{l}\text { 1) территория происхожде- } \\
\text { ния или проживания }\end{array}$ \\
\hline Дверь & $\begin{array}{l}\text { 1) пространство, место; } \\
\text { 2) открыта }\end{array}$ & 1) открыта \\
\hline Окно & $\begin{array}{l}\text { 1) закрыто, занавешено; } \\
\text { 2) взгляд снаружи внутрь; } \\
\text { 3) тайный вход; } \\
\text { 4) граница между миром } \\
\text { живых и мертвых }\end{array}$ & $\begin{array}{l}\text { 1) открыто; } \\
\text { 2) взгляд изнутри наружу; } \\
\text { На периферии: } \\
\text { 3) тайный вход; } \\
\text { 4) граница между миром } \\
\text { живых и мертвых }\end{array}$ \\
\hline Ворота & $\begin{array}{l}\text { 1) граница; } \\
\text { 2) место встречи; } \\
\text { 3) пространство, место }\end{array}$ & $\begin{array}{l}\text { 1) граница; } \\
\text { На периферии: } \\
\text { 2) место встречи }\end{array}$ \\
\hline Калитка & $\begin{array}{l}\text { 1) открыта; } \\
\text { 2) обеспечивает проницае- } \\
\text { мость границ }\end{array}$ & 1) открыта \\
\hline Крыльцо & $\begin{array}{l}\text { 1) сцена, возвышение; } \\
\text { 2) пространство, место; } \\
\text { 3) граница }\end{array}$ & $\begin{array}{l}\text { 1) пространство, место; } \\
\text { 2) граница }\end{array}$ \\
\hline Забор & $\begin{array}{l}\text { 1) непреодолимая преграда; } \\
\text { 2) смерть }\end{array}$ & 1) преодолимая преграда \\
\hline
\end{tabular}

Проведенная реконструкция фрагмента ТекстАП пространственного предела позволяет определить инвариантное ядро поля, общее для всех носителей русского языка, а также выявить некоторые особенности языковой личности Ф.М. Достоевского. Кроме этого, сопоставительный анализ идиоглосс, входящих в одну парадигму, дает возможность более полно охарактеризовать их символические значения. Например, слова, объединенные в группу с общим значением пространственного 
предела, тесно связаны с представлением о разделении свой - чужой, что характерно для русской национальной языковой личности, а в текстах Ф.М. Достоевского выражено особенно ярко: для него пересечение границы если не невозможно (забор, стена), то, по крайней мере, влечет за собой важные для героя последствия. Значительная разница в количестве ассоциаций, связанных с преодолением забора, позволяет сделать вывод о том, что в языковой картине мира русских забор - это преодолимая преграда.

Идиоглоссы, реализующие значение границы, порога, вместе с тем символизируют самостоятельное пространство, место действия, где происходят значимые события, где человека может поджидать опасность или неожиданность. В текстах Ф.М. Достоевского реализуется не только общее, характерное для всех носителей русского языка значение порога как предела, но и индивидуальное для писателя восприятие порога как самостоятельного пространства, отдельного от внешнего и внутреннего мира места, которое иногда трактуется как «пространство внутри пространства», обладающее «топологическими качествами» [Подорога, 1995, с. 132].

При сопоставлении идиоглосс со значением 'способ пересечь границу', к которым относятся дверь, окно и калитка, бросается в глаза их противопоставленность друг другу по признаку 'открыт/закрыт' в ассоциативно-вербальной сети Ф.М. Достоевского: если дверь и калитка чаще открыты, то окно закрыто или занавешено. Последнее характеризует индивидуальные особенности языковой личности Ф.М. Достоевского, т.к. не совпадает с представлениями об окне большинства носителей русского языка. В «Кроткой» героиня совершает самоубийство, выпав из окна, что связывает идиоглоссу окно не только с группой слов со значением пространственного предела, но и со словами, объединенными общим смыслом 'преступление' [Ружицкий, 2014, с. 139]. Таким образом, идиоглосса окно входит в состав не одного ТекстАП, а по крайней мере двух, что позволяет установить некоторые характеристики внешней структуры исследуемого ТекстАП (подробнее о двух уровнях ассоциативных связей см. [Караулов, 2015]).

Окно указывает и на другие различия. Ф.М. Достоевскому свойственен взгляд снаружи внутрь окна, при этом в окно, по его представлениям, можно не только заглядывать, но и войти. Окно как медиатор между живым и мертвым миром - символ, характерный для русской языковой картины мира в целом, однако слабо выраженный.

Символическое значение ворот как места встречи относится, предположительно, к общим чертам русской языковой личности, а крыльцо, 
отождествляющееся со сценой, - характерная особенность тезауруса Ф.М. Достоевского.

Калитка, как и дверь, представляется носителям русского языка преимущественно открытой, а также выступает объектом, который соединяет два пространства - свое и чужое, знакомое и незнакомое. Надо отметить, что калитка, находящаяся в воротах, часто объединяет в себе символические функции этих двух идиоглосс.

Таким образом, группа слов со значением пространственного предела осмыслена Ф.М. Достоевским в близких для него понятиях биполярности свой - чужой, открытый - закрытый, живой - мёртвый, пространство - граница, проницаемость - непроницаемость, которые парадоксальным образом могут соединяться в одном текстовом ассоциативном поле.

\section{Библиографический список / References}

Арбан, 1976 - Арбан Д. «Порог» у Достоевского (тема, мотив и понятие) // Достоевский. Материалы и исследования. Т. 2. Л., 1976. С. 19-29. [Arban D. Dostoyevsky's 'threshold' (subject, topic and concept). Dostoevskii. Materialy i issledovaniya. Vol. 2. Leningrad, 1976. Pp. 19-29.]

Байбурин, 1983 - Байбурин А.К. Жилище в обрядах и представлениях восточных славян. Л., 1983. [Baiburin A.K. Zhilishche v obryadakh i predstavleniyakh vostochnykh slavyan [The Eastern Slavs' rites and notions of dwelling]. Leningrad, 1983.]

Бахтин, 1979 - Бахтин М.М. Проблемы поэтики Достоевского. 4-е изд. М., 1979. [Bakhtin M.M. Problemy poetiki Dostoevskogo [Problems of Dostoyevsky's poetics]. 4th ed. Moscow, 1979.]

Венедиктова, 2008 - Венедиктова Т.Д. Люди и стены: осмысление повседневности в литературе (Г. Мелвилл и Ф.М. Достоевский). 2008. URL: http:// forlit.philol.msu.ru/lib-ru/venediktova1-ru (дата обращения: 30.04.2018). [Venediktova T.D. People and walls: literature perception of everyday life (Melville G. and Dostoyevsky F.). 2008. URL: http://forlit.philol.msu.ru/lib-ru/venediktova1-ru.]

Гессе, 2010 - Гессе Г. Магия книги: Эссе о литературе. СПб., 2010. [Hesse Н. Magiya knigi: Esse o literature [The magic of a book: Essay about literature]. St. Petersburg, 2010.]

Горбунова, 1992 - Горбунова Г.З. Короленко и Достоевский (художественноэтические искания): Автореф. дис. ... канд. филол. наук. Томск, 1992. [Gorbunova G.Z. Korolenko i Dostoevskii (khudozhestvenno-eticheskie iskaniya) [Korolenko and Dostoyevsky (art and ethics quest)]. PhD thesis. Tomsk, 1992.]

Достоевский - Достоевский Ф.М. Собр. соч. в 15 т. Л., 1989-1996. [Dostoevsky F.M. Sobranie sochinenij v 15 tomah [Collected works in 15 volumes]. Leningrad, 1989-1996.]

Карасев, 1994 - Карасев Л.В. О символах Достоевского // Вопросы философии. 1994. № 10. С. 90-111. [Karasev L.V. About Dostoyevsky’s symbols. Voprosy filosofii. 1994. № 10. Pp. 90-111.] 
Караулов, 1999 - Караулов Ю.Н Активная грамматика и ассоциативно-вербальная сеть. М., 1999. [Karaulov Yu.N. Aktivnaya grammatika i assotsiativnoverbal'naya set' [Active grammar and associative verbal network]. Moscow, 1999.]

Караулов, 2014 - Караулов Ю.Н. От словаря языка писателя к познанию его мира // Слово Достоевского 2014. Идиостиль и картина мира: Коллективная монография / Под общ. ред. Е.А. Осокиной. М., 2014. С. 116-131. [Karaulov Yu.N. From author's language dictionary to his world comprehension. Slovo Dostoevskogo 2014. Idiostil' i kartina mira. E.A. Osokina (ed.). Moscow, 2014. Pp. 116-131.]

Караулов, 2015 - Караулов Ю.Н. Ассоциативный анализ: новый подход к интерпретации художественного текста // Вопросы психолингвистики. 2015. № 3 (25). C. 14-35. [Karaulov Yu.N. Associative analysis: The new approach to fiction interpretation. Voprosy psikholingvistiki. 2015. № 3 (25). Pp. 14-35.]

Караулов, Гинзбург, 2002 - Караулов Ю.Н., Гинзбург Е.Л. Язык и мысль Достоевского в словарном отображении // Словарь языка Достоевского. Лексический строй идиолекта. Вып. первый / Гл. ред. Ю.Н. Караулов. М., 2002. C. IX-LXIII. [Karaulov Yu.N., Ginzburg E.L. Dostoyevsky's language and thought in dictionary presentation. Slovar' yazyka Dostoevskogo. Leksicheskii stroi idiolekta. Vol. I. Yu.N. Karaulov (ed.). Moscow, 2002. Pp. IX-LXIII.]

Кирло, 2010 - Кирло Х. Словарь символов. 1000 статей о важнейших понятиях религии, литературы, архитектуры, истории. М., 2010. [Kirlo J. Slovar' simvolov. 1000 statei o vazhneishikh ponyatiyakh religii, literatury, arkhitektury, istorii [Symbol dictionary. 1000 articles about the most important concepts of religion, literature, architecture and history]. Moscow, 2010.]

Криницын, 2009 - Криницын А.Б. Генезис и идейное становление подпольного героя в творчестве Ф.М. Достоевского. 2009. URL: http://www.portal-slovo. ru/philology/41481.php (дата обращения: 30.04.2018). [Krinitsyn A.B. Genesis and outlook formation of the underground character in Dostoyevsky's novels. 2009. URL: http://www.portal-slovo.ru/philology/41481.php.]

Подорога, 1995 - Подорога В.А. Человек без кожи (материалы к исследованию Достоевского) // Социальная философия и философская антропология: труды и исследования. М., 1995. С. 126-160. [Podoroga V.A. Skinless man (data for research on Dostoyevsky). Sotsial'naya filosofiya i filosofskaya antropologiya: trudy $i$ issledovaniya. Moscow, 1995. Pp. 126-160.]

РАС - Русский ассоциативный словарь: В 2 т. / Ю.Н. Караулов, Г.А. Черкасова, Н.В. Уфимцева и др. М., 2002. [Karaulov Yu.N., Cherkasova G.A., Ufimceva N.V. et al. Russkii assotsiativnyi slovar': v 2 t. [Russian associative dictionary: in two volumes]. Vol. I, II. Moscow, 2002.]

Ружицкий, 2008 - Ружицкий И.В. Символическое употребление слова в произведениях Ф.М. Достоевского // Мир русского слова. 2008. № 1. С. 58-63. [Ruzhitskii I.V. Symbolic word usage in Dostoyevsky's novels. Mir russkogo slova. 2008. № 1. Pp. 58-63.]

Ружицкий, 2014 - Ружицкий И.В. От символической картины мира к тезаурусу (о возможности реконструкции языковой личности Ф.М. Достоевского) // Слово Достоевского 2014. Идиостиль и картина мира: Коллективная монография / Под общ. ред. Е.А. Осокиной. М., 2014. С. 132-141. [Ruzhitskii I.V. From symbolic view of the world to thesaurus (about possibility of reconstruction of Dostoyevsky's linguistic identity). Slovo Dostoevskogo 2014. Idiostil' i kartina mira. E.A. Osokina (ed.). Moscow, 2014. Pp. 132-141.] 
Ружицкий, 2015 - Ружицкий И.В. Языковая личность Ф.М. Достоевского: лексикографическое представление: Дис. ... д-ра филол. наук. М., 2015. [Ruzhitskii I.V. Yazykovaya lichnost' F.M. Dostoevskogo: leksikograficheskoe predstavlenie [Dostoyevsky's linguistic identity: Lexicographic presentation]. Dr. diss. Moscow, 2015.]

СЯД - Словарь языка Достоевского. Лексический строй идиолекта / Гинзбург Е.Л., Караулов Ю.Н., Коробова М.М. и др.; Под ред. Ю.Н. Караулова. T. I. М., 2001. T. II-III. М., 2003. Словарь языка Достоевского: Идиоглоссарий / Гинзбург Е.Л., Караулов Ю.Н., Коробова М.М. и др.; Под ред. Ю.Н. Караулова. T. I (А-B). М., 2008. Т. II (Г-3). М., 2010. Т. III (И-М). М., 2012. Т. IV (Н-По). M., 2017. [Ginzburg E.L., Karaulov Yu.N., Korobova M.M. et al. Slovar' yazyka Dostoevskogo. Leksicheskii stroi idiolekta [Dostoyevsky's language dictionary. Lexical idiolect system]. Yu.N. Karaulov (ed.). Vol. I. Moscow, 2001. Vol. II-III. Moscow, 2003. Ginzburg E.L., Karaulov Yu.N., Korobova M.M. et al. Slovar' yazyka Dostoevskogo: Idioglossarii [Dostoyevsky's language dictionary: Idioglossary]. Yu.N. Karaulov (ed.). Vol. I (A-V). Moscow, 2008. Vol. II (G-Z). Moscow, 2010. Vol. III (I-M). Moscow, 2012. T. IV (N-Po). Moscow, 2017.]

Тэрнер, 1983 - Тэрнер В. Символ и ритуал. М., 1983. [Turner V. Simvol i ritual [Symbol and rite]. Moscow, 1983.]

Статья поступила в редакцию 14.05.2018

The article was received on 14.05.2018

Конкина Наиля Ринатовна - аспирант отдела экспериментальной лексикографии, Институт русского языка им. В.В. Виноградова РАН, г. Москва

Konkina Nailya R. - post-graduate student at the Department of Experimental Lexicography, Vinogradov Institute of Russian Language, RAS, Moscow

E-mail: nailya.andante@gmail.com 